\title{
PENINGKATAN HASIL BELAJAR PENDIDIKAN AGAMA ISLAM MELALUI MODEL PEMBELAJARAN TEAM ASSISTED INDIVIDUALIZATION PADA SISWA KELAS V SDN MEKAR SARI
}

\author{
Muhiddin \\ Sekolah Dasar Negeri Mekar Sari \\ Jalan Mekar Sari, Kec. Tatah Makmur, Kab. Banjar, Kalimantan Selatan \\ Email: muhiddin601@yahoo.com
}

Website: https://jurnal.uin-antasari.ac.id/index.php/adzka

Received: 10 Desember 2019; Accepted: 10 Januari 2020; Published: 12 Januari 2019

\begin{abstract}
The purpose of this study was to determine the improvement of PAI learning outcomes through the TAI learning model on the story of the Khalifah Abu Bakar R.A. In this study using the Classroom Action Research method, which uses two cycles with 4 stages in each cycle, namely planning, implementation, observation, and reflection. Data collection techniques in the form of observation sheets on teacher and student activities and student learning outcomes tests. The instrument of teacher and student activities is to determine the level of implementation of active actions during learning, as well as the tests held at each meeting in each cycle. In the two activities carried out the teacher got an sekali excellent 'qualification. Student activity is dominated by the activity of the very active and active category. Complete classical learning outcomes $57.14 \%$ achieved at the first and second meetings, $71.43 \%$ at the third meeting, $78.57 \%$ at the fourth meeting reached 92.86\%. The use of TAI (Team Assisted Individualization) can increase the activeness of teachers and students as well as student learning outcomes in the Story of Caliph Abu Bakar R.A. in Elementary School 2018/2019. Keywords: cooperative learning model; islamic education; teams assissted individualization
\end{abstract}

\begin{abstract}
ABSTRAK
Tujuan penelitian ini adalah untuk mengetahui peningkatan hasil belajar PAI melalui model pembelajaran TAI pada materi Kisah Khalifah Abu Bakar R.A. Pada penelitian ini menggunakan metode Penelitian Tindakan Kelas, yang menggunakan dua siklus dengan 4 tahapan pada masing-masing siklusnya, yaitu perencanaan, pelaksanaan, observasi, dan refleksi. Teknik pengumpulan data berupa lembar observasi pada aktivitas guru dan siswa dan tes hasil belajar siswa. Instrumen aktivitas guru dan siswa untuk mengetahui tingkat keterlaksanaan tindakan keaktifan saat pembelajaran, serta diadakan tes pada tiap pertemuan di tiap siklus. Pada dua keterlaksanaan aktivitas guru mendapat kualifikasi 'baik sekali'. Aktivitas siswa didominasi keaktifan kategori sangat aktif dan aktif. Ketuntasan hasil belajar klasikal 57.14\% dicapai pada pertemuan kesatu dan kedua, $71.43 \%$ pada pertemuan ketiga, $78.57 \%$ pada pertemuan keempat mencapai 92.86\%. Penggunaan TAI (Team Assisted Individualization) dapat meningkatkan keaktifan guru dan siswa serta hasil belajar siswa pada Kisah Khalifah Abu Bakar R.A. di SDN Pelajaran 2018/2019.
\end{abstract}

Kata Kunci : model pembelajaran kooperatif; pendidikan agama islam; teams assissted individualization

\section{PENDAHULUAN}

Pada implementasinya, pendidikan di sekolah dasar dilaksanakan melalui proses pembelajaran yang menggunakan suatu kurikulum sebagai acuan penyelenggaraan (Anwar dan Harmi, 2010: 1). Kenyataan yang terjadi selama ini permasalahan belajar, ulangan harian 
2018/2019 dari 14 hanya 7 orang siswa yang nilainya tuntas, yakni 50\% siswa .Selain itu penyebab dari permasalahan kurangnya pemahaman siswa yang konkrit, pembelajaran cenderung masih bersifat abstrak sehingga menjadi kurang termotivasi untuk belajar.

Proses pembelajaran yang terjadi seperti itu, jika dibiarkan terus menerus akan menyebabkan siswa tidak menguasai konsep dengan baik. Pada pembelajaran Pendidikan Agama Islam pada materi Perilaku Terpuji tentang Kisah Khalifah Abu Bakar R.A. Kelas V SDN Mekar Sari Kecamatan Tatah Makmur Kabupaten Banjar, siswa kurang aktif dalam kelompoknya untuk memecahkan suatu permasalahan yang berkaitan dengan pembelajaran berdasarkan pengalaman yang dimilikinya. Selain itu, siswa pun kurang merasa senang karena tidak mendapatkan pengalaman yang baru dan mengalami sendiri kegiatan tersebut, sehingga pelajaran tersebut pun kurang bisa diterima dengan baik. Pada pemberian tugas secara berkelompok, siswa cenderung ribut sendiri, sehingga pembelajaran tidak dapat berjalan dengan baik.

Pemilihan mata pelajaran didasarkan pada rendahnya sebelumnya seperti tergambar II yang hanya mencapai nilai rata-rata 50\%. Pemilihan pembelajaran materi Kisah Khalifah Abu Bakar R.A. didasarkan pada kompleksitas materi yang cukup luas dibandingkan materi lainnya sehingga dialokasikan 16 Jam pelajaran berdasarkan silabus yang dikembangkan sekolah menurut Kurikulum Tingkat Satuan Pendidikan KTSP. Kompleksitas materi tersebut dinilai perlu untuk ditingkatkan hasil belajarnya karena akan memiliki kontribusi pada nilai siswa keseluruhan pada semester II ini. Selain itu dalam beberapa tahun Ujian Nasional yang diselenggarakan, Kisah Khalifah Abu Bakar R.A. selalu menjadi salah satu indikator dalam (SKL) untuk sehingga perlu untuk mendapat perhatian.

Selain itu, permasalahan yang dihadapi pada mata pelajaran Pendidikan Agama Islam, khususnya materi Kisah Khalifah Abu Bakar R.A. pada Tahun Pelajaran 2018/2019 berdasarkan 2 Mekar Sari Tatah Makmur Banjar masih berada dibawah standar ketuntasan minimal. Guru masih bersifat abstrak dalam memberikan pembelajaran. Hal ini harus segera dicarikan solusi, yaitu dengan menggunakan model pembelajaran Pendidikan Agama Islam yang bermakna bagi siswa. Menyikapi masalah ini, maka diperlukan pembelajaran individu yang memiliki beberapa keunggulan menurut Widdiharto (2006:19). Oleh sebab itu, salah satu model pembelajaran kooperatif yang dapat digunakan dalam materi ini adalah model Team Assissted Individualization (TAI).

Adapun langkah-langkah harus dilakukan penerapan TAI, yaitu membuat kelompok secara heterogen masing-masing kelompoknya 3-4; yang disampaikan; tugas kepada setiap anggota kelompok; tugas dikerjakan sesuai kemampuan masing-masing kemudian tugas dibawa kekelompok masing-masing; perwakilan kerja kelompoknya; kesimpulan/penutup. Sintaks Model tersebut menyajikan masalah/fenomena relevan, membimbing siswa dalam membuat prediksi (berhipotesis), mempersiapkan perlengkapan melaksanakan diskusi, mencatat hasil diskusi membuat analisa, membuat kesimpulan, membimbing siswa dalam penyampaian presentasi dan mengarahkan pada kesimpulan relevan. Penelitian bertujuan untuk peningkatan aktivitas guru; aktivitas siswa; dan hasil belajar siswa kelas $\mathrm{V}$ pada mata pelajaran Pendidikan Agama Islam materi Kisah Khalifah Abu Bakar R.A. menggunakan TAI pada SDN Mekar Sari Tatah Makmur Banjar Pelajaran 2018/2019.

\section{METODE PENELITIAN}

Penelitian Tindakan Kelas merupakan suatu tindakan dalam kelas (Kemmis dalam Arikunto dkk, 2006:22). Suatu akar permasalahannya muncul di kelas, oleh dan untuk manfaat kelas (Sholikin, 2008:14). Prinsip dalam pelaksanaan penelitian tindakan kelas, yaitu bertujuan untuk memperbaiki mutu proses belajar mengajar; menjadikan guru berfikir kritis sistematis dan terbiasa melakukan aktivitas yang bernilai akademik ilmiah; serta dimulai dari permasalahan pembelajaran yang sederhana, konkret, jelas dan tajam. 
Tujuan penelitian tindakan kelas adalah membantu guru dan tenaga kependidikan lainnya mengatasi masalah pembelajaran; meningkatkan sikap professional pendidik dan tenaga kependidikan; meningkatkan profesionalisme guru. Tahap PTK menurut Arikunto (2006), seperti yang digambarkan pada bagan berikut:

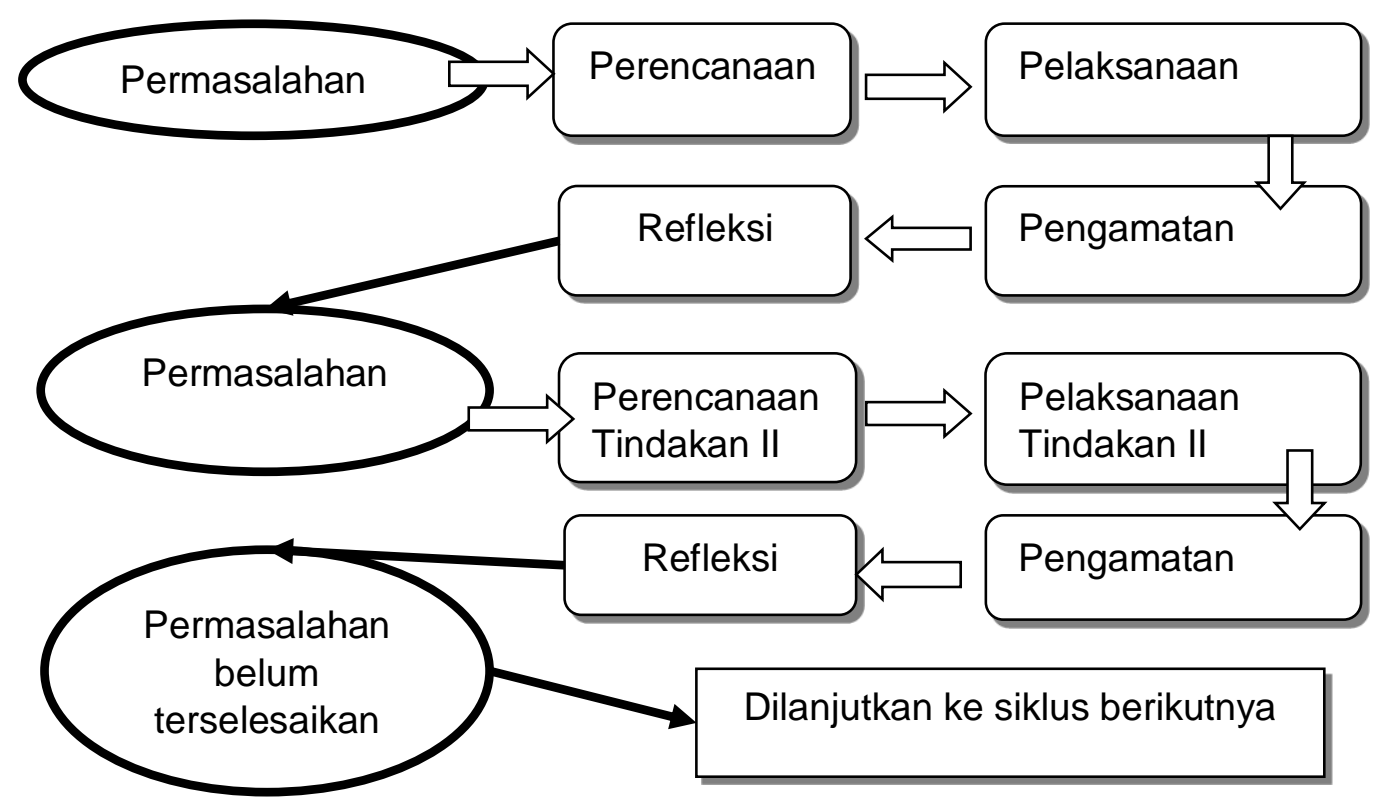

Gambar 1. Tahapan PTK Setiap Siklus

Penelitian dilaksanakan di SDN Mekar Sari kelas V sebanyak 14 siswa sebagai sampelnya. Secara umum fasilitas kelas mendukung berlangsungnya proses belajar mengajar. Dipilihnya kelas V sebagai tempat penelitian tindakan kelas berkaitan dengan materi Khalifah Abu Bakar R.A. Pada proses pembelajaran, observasi dilaksanakan pada aktivitas guru yang meliputi keterlaksanaan dalam penerapan sintaks tiap tindakan pada setiap pertemuan sesuai perencanan pembelajaran yang telah disusun. Sintaks-sintaks tersebut dinilai keterlaksanaannya menggunakan lembar observasi kegiatan guru oleh seorang observer. Selain itu, observasi juga dilaksanakan pada aktivitas siwa kelas $\mathrm{V}$ pada pembelajaran tersebut yang meliputi aktivitas perorangan siswa dalam merespon masalah yang disajikan, menentukan hipotesis, melakukan persiapan dan melaksanakan diskusi serta menganalisa hasil diskusi, menyimpulkan hasil kegiatan dan mempresentasikannnya. Selain itu, hasil belajar kognitif siswa juga diukur melalui tes hasil belajar.

\section{Skenario Tindakan:}

\section{Perencanaan}

Membuat, mengarahkan, dan mengembangkan pemikirannya untuk melakukan kegiatan belajar bermakna, berkesan, baik dengan cara meminta siswa untuk bekerja sendiri mencari serta menemukan jawabannya, kemudian memfasilitasi siswa mengkonstruksi sendiri pengetahuannya keterampilannya yang baru saja ditemuinya.

2. Pelaksanaan Tindakan

Kegiatan pembelajaran pada setiap siklus skenario yang telah direncanakan dalam RPP. Berikut skenario langkah model pembelajaran TAI:

a. Kegiatan Awal

1) Melakukan apersepsi 
2) Memotivasi siswa terlibat dalam pemecahan masalah yang dipilihMenyampaikan tujuan pembelajaran yang dicapai

b. Kegiatan Inti

1) Membagi 4 kelompok yang terdiri dari 3-4 orang.

2) Menemukan pemecahan masalah.

3) Pemecahan masalah dan memberikan penjelasan.

4) Mengembangkan dan menyajikan hasil karya

5) Membimbing untuk menyajikan kemudian penyelesaian masalah

c. Kegiatan Akhir

1) Mengadakan evaluasi tertulis

2) Melaksanakan refleksi dan tindak lanjut

3. Observasi

a. Observasi guru terhadap murid.

b. Observasi observer terhadap guru.

4. Tahap Refleksi

Refleksi dalam tindakan dengan merenungkan kembali hasil dicatat dalam observasi. Hasil dari setiap pelaksanaan penelitian dianalisis, direfleksikan dan disimpulkan kembali agar dapat dilaksanakan perbaikan terhadap kelemahan yang terjadi dan dicari cara pemecahan yang terbaik. Kemudian diterapkan jalan yang terbaik untuk meningkatkan kemampuan siswa dalam memahami materi "Kisah Khalifah Abu Bakar R.A. TAI.

Data hasil observasi guru dan siswa serta hasil belajar siswa dianalisis secara deskriptif menggunakan rumus yang sudah ditentukan. Teknik analisis data menggunakan rumus berikut: 1) Data Aktivitas Guru dan Siswa

Diambil dari hasil aktivitas guru dan data keaktivan siswa yang keduanya melalui pengolahan data dilakukan dengan rumus:

$$
\text { Aktivitas }=\frac{\text { Jumlah skor }}{\text { Jumlah skor Keseluruha } \mathrm{n}} \times 100 \%
$$

\section{2) Data Belajar}

Data hasil belajar dari tes tertulis yang diberikan kepada siswa setiap akhir pertemuan, diolah dengan kriteria berikut:

Kriteria ketuntasan belajar:

a. $\geq 60$ (KKM Sekolah).

b. Jika $\geq 80 \%$ dari seluruh siswa telah mencapai ketuntasan individual

(BSNP Depdiknas, 2007:30).

Pelaksanaan tindakan dinyatakan berhasil apabila tiap pertemuan dicapai indikator. Dalam aktivitasnya Kooperatif Tipe TAI (Team Assisted Individualization) minimal keterlaksanan baik tiap pembelajaran. Pada tiap pertemuan aktivitas siswa minimal pada kualifikasi keaktifan 'baik' dengan persentase mencapai $\geq 75 \%$. Hasil belajar dapat dikatakan berhasil apabila diperoleh nilai $\geq 70$ dengan ketuntasan klasikal sebesar $\geq 80 \%$

\section{HASIL PENELITIAN DAN PEMBAHASAN}

1. Pembelajaran PAI dengan TAI pada Siklus I

a. Pelaksanaan Pembelajaran

Pembelajaran siklus I dilaksanakan sebanyak dua kali pertemuan dengan 4 jam pelajaran. Berikut gambaran pelaksanaan pembelajaran pada siklus I.

1) Pertemuan 1 
Pelaksanaan pertemuan I dilaksanakan selama 2 jam pelajaran dengan gambaran sebagai berikut:

Guru dan siswa mempersiapkan pembelajaran, kemudian guru merapikasn siswa tertib. Guru memberikan motivasi belajar kepada siswa sehingga siswa termotivasi dalam belajar. Guru membentuk 4 kelompok. Kemudian menyajikan pelajaran dengan menggunakan alat bantu atau media pembelajaran, siswa diarahkan untuk memperhatikan penjelasan guru pada saat menerangkan materi pembelajaran setelah itu guru mengaktifkan siswa dengan memberi tugas kepada setiap individu dalam kelompok untuk dikerjakan oleh anggota kelompok, meminta tugas sesuai kempuannya kemudian tugas yang sudah dikerjakan dibawa kekelompok masingmasing untuk didiskusikan dan dibahas, guru memberi penghargaan yang mendapatkan nilai tertinggi. Diakhir pembelajaran guru kembali lagi menyajikan materi pembelajaran. Menyimpulkan dan guru kemudian memberikan umpan balik .

2) Pertemuan 2

Apersepsi dengan menanyakan pembelajaran telah lalu kemudian membuka sebuah permasalahan yang isinya berkaitan dipelajari saat ini. Menanyakan salah satu apa terkait pertanyaan appersepsi yang diberikan. Kemudian guru mengikuti kegiatan, setelah penyampaian, guru menyampaikan atau menjelaskan cakupan. Kemudian 3-4, dengan pembagian kelompok secara heterogen. Selama pembagian kelompok ini suasana sedikit kacau dan gaduh, karena rata-rata siswa ingin sekelompok dengan teman pilihannya sendiri. Namun, suasana ini tidak terjadi berlarut-larut serta dapat dikembalikan kondusif seperti semula.

Setelah selesai teman masing-masing, diarahkan curah pendapat dalam permasalahan yang diajukan guru. Guru mendekati setiap kelompok untuk memberikan pendapatnya terhadap permasalahan yang disajikan guru. Setelah curah pendapat oleh tiap kelompok mengenai hipotesis atas membimbing dan menjelaskan tentang permasalahan yang sedang dibahas. Kemudian guru memberikan bimbingan kepada tiap kelompok untuk mendapat informasi yang dilakukan, yaitu dengan memberikan arahan atau petunjuk apabila ada kelompok yang kesulitan dalam mendapatkan informasi dari kegiatan yang dilakukan.

Setelah kelompok selesai melakukan kegiatan, kemudian guru memberikan dari kegiatan dilakukan membacakan hasil kerjanya didepan kelas, sementara mendengarkan dan terhadap menyampaikan kegiatan, baik berupa pertanyaan ataupun tambahan pendapat guna melengkapi hasil. Kemudian meminta untuk mengembalikan alat kelompoknya ke depan (meja guru) dan merapikan seperti dan ketempat seperti semula. Setelah selesai proses pembelajaran, guru bersama-sama siswa membuat kesimpulan dengan memberikan pertanyaan-pertanyaan kepada siswa telah dilaksanakan telah juga mengingatnya. Selanjutnya, guru memberikan soal mandiri tidak bekerja sama dengan temannya. Pemberian soal evaluasi pelajaran. yang baru diberikan, kemudian mengucapkan salam memberikan nasehat kepada siswa.

\section{b. Hasil Observasi}

\section{1) Hasil Observasi Aktivitas Guru}

Berdasarkan hasil observasi, pada aktivitas guru pertemuan 1 mendapat skor 14 dan tergolong "cukup". Dalam aktivitas ini perlu agar nantinya mendapatkan aktivitas belum mencapai target diharapkan, yaitu aktivitas guru dikatakan berhasil apabila mencapai skor 1624, atau berada pada kategori baik aktivitas harus ditingkatkan, khususnya pada dalam memberikan bimbingan individu dalam kelompok, aspek mengarahkan siswa, dan aspek membuat kesimpulan. Pada pertemuan 2, meningkat menjadi 17 point dengan kategori "baik". Hal ini membuktikan bahwa dari pertemuan 1 ke 2, aktivitas guru mengalami peningkatan.

\section{2) Hasil Observasi Aktivitas Siswa}

Berdasarkan hasil observasi, aktivitas siswa pada pertemuan pertama mendapatkan skor ketuntasan sebanyak 50\% dengan kategori "aktif'. Sedangkan pada pertemuan kedua, aktivitas siswa meningkat menjadi 64,29\%. Perbandingan aktivitas siswa per kategori ditunjukkan pada grafik berikut. 


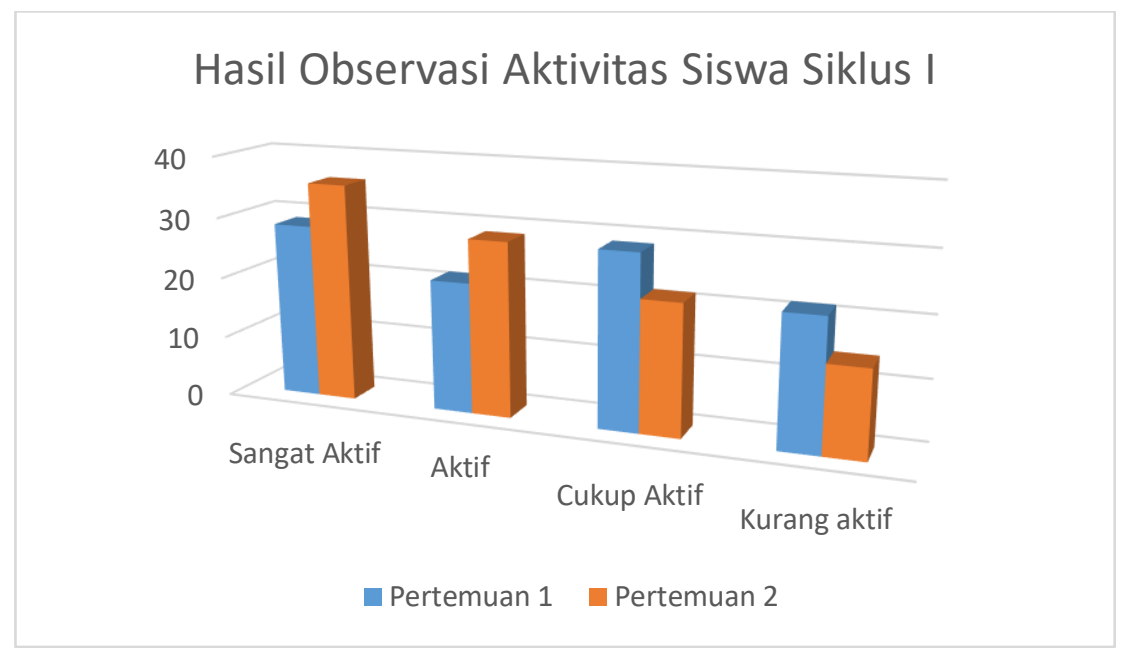

Gambar 2. Diagram Hasil Observasi Aktivitas Siswa Siklus I

\section{3) Hasil Belajar}

Pada pertemuan 1, sebanyak 2 siswa mendapatkan nilai 90 (14,29\%); 3 siswa mendapatkan nilai $80(21,43 \%) ; 3$ siswa mendapat nilai $70(21,43 \%) ; 3$ siswa mendapat nilai 60 (21,43\%); dan 3 siswa mendapat nilai 50 (21,43\%). Dengan demikian, sebanyak 8 siswa telah lulus KKM dengan persentase 57,14\%; dan 6 siswa belum lulus KKM dengan persentase $42,86 \%$. Sedangkan pada pertemuan 2, ketuntasan siswa meningkat menjadi 71,43\% dengan jumlah siswa sebanyak 10 orang, sedangkan 4 orang $(28,57 \%)$ siswa belum tuntas. Pada pertemuan 2, sebanyak 3 siswa mendapat nilai 100; 3 siswa mendapat nilai 90; 2 siswa mendapat nilai 80; 2 siswa mendapat 70; 2 siswa mendapat nilai 60; 2 siswa mendapat nilai 50. Perbandingan hasil belajar siswa di pertemuan 1 dan 2 ditunjukkan pada bagan berikut.

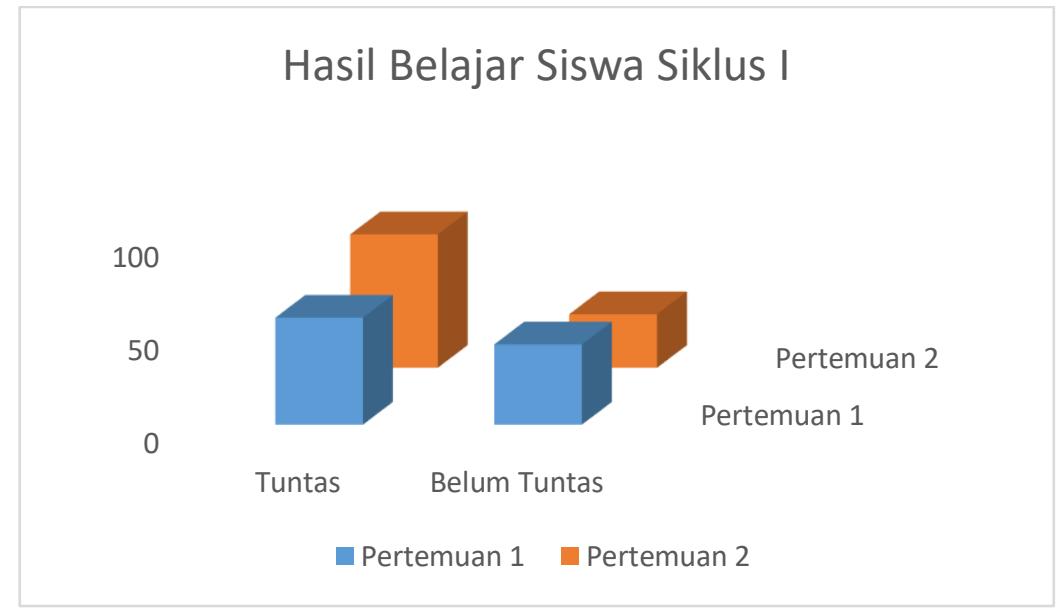

Gambar 3. Diagram Hasil Belajar Siswa Siklus I

\section{c. Refleksi}

Proses pembelajaran semua aspek telah dilakukan oleh guru, dalam penerapannya diperbaiki, yaitu pada aktivitas guru dalam memberikan bimbingan dalam kelompok, guru harus dapat benar-benar menanamkan kepada siswa, kelompok dan juga aktivitas guru dalam membimbing siswa pada saat menyampaikan hasil diskusi didepan kelas, guru harus lebih tanggap lagi dalam membimbing siswa, kemudian pada aktivitas memuat kesimpulan guru harus bisa bagaimana membuat komunikasi multi arah agas pada saat membuat kesimpulan terlibat, selain itu aspek yang lainnya juga harus lebih ditingkatkan lagi agar kualitas pembelajaran lebih 
meningkat sesuai dengan harapan. Sehingga aktivitas guru dapat mencapai dari indikator yang telah ditentukan sebelumnya.

Dalam pelaksanaan menunjukkan persentase klasikal yang diperoleh sebesar $50 \%$ dengan jumlah siswa yang berada pada keterangan aktif adalah 7 orang, secara klasikal aktifitas siswa. Hal ini menunjukkan belum sepenuhnya dilaksanakan siswa secara optimal atau ketercapaian. Berdasarkan, aktivitas dikatakan berhasil apabila berada pada kategori minimal aktif, dan persentase keaktifan klasikal siswa $\geq 80 \%$. Tergolong bagi siswa kelihatan masih kurang mampu bekerja sama dengan anggota kelompoknya karena siswa terbiasa melaksanakan tugas secara individu. Dalam kegiatan curah pendapat mengenai permasalahan maupun terlihat dalam memberikan tanggapan atau dorongan kepada siswa.

Pertemuan 1 ini mendapatkan atau dinyatakan tuntas adalah 8 orang. Berdasarkan seorang dikatakan atau tuntas dalam dan $\geq 80 \%$. Persentase siswa pertemuan 1 ini $57.14 \%$. Rendahnya pertemuan ini banyak aktivitas yang sukar dalam melakukan curah pendapat, mencari informasi melalui diskusi tersebut, serta proses diskusi dan tanya jawab yang masih kurang, dikarenakan siswa kurang percaya diri atau malu-malu dalam mengemukakan pendapatnya. Ini disebabkan siswa masih terbiasa dengan gaya belajar lama, sehingga aktivitas siswa dalam bekerja secara kelompok masih kurang, yang berdampak pada pertemuan selanjutnya, bisa meningkatkan interaksi antar siswa dalam bekerja sama secara kelompok dan juga atau dorongan memiliki sikap mengemukakan pendapatnya.

Pertemuan dengan skor 17 kategori proses pembelajaran semua aspek telah dilakukan oleh guru, dalam penerapannya diperbaiki, yaitu pada aktivitas guru dalam memberikan bimbingan dalam kelompok, guru harus dapat benar-benar menanamkan kepada siswa kelompok dan juga aktivitas guru dalam membimbing siswa pada saat menyampaikan hasil diskusi didepan kelas, guru harus lebih tanggap lagi dalam membimbing siswa, kemudian pada aktivitas memuat kesimpulan guru harus bisa bagaimana membuat komunikasi multi arah agas pada saat membuat kesimpulan terlibat selain itu aspek yang lainnya juga harus lebih ditingkatkan lagi agar kualitas pembelajaran lebih meningkat sesuai dengan harapan. Sehingga aktivitas guru dapat mencapai dari indikator yang telah ditentukan sebelumnya.

Dalam pelaksanaan menunjukkan 64,29\% jumlah siswa yang berada pada keterangan aktif adalah 9 orang, secara klasikal aktifitas siswa. Hal ini menunjukkan belum sepenuhnya dilaksanakan siswa secara optimal atau ketercapaian. Berdasarkan, aktivitas dikatakan berhasil apabila berada pada kategori minimal aktif, dan persentase keaktifan klasikal siswa $\geq 80 \%$. Tergolong bagi siswa kelihatan masih kurang mampu bekerja sama dengan anggota kelompoknya karena siswa terbiasa melaksanakan tugas secara individu. Dalam kegiatan curah pendapat mengenai permasalahan maupun terlihat dalam memberikan tanggapan atau dorongan kepada siswa.

Pertemuan 2 ini mendapatkan atau dinyatakan tuntas adalah 10 orang. Berdasarkan seorang dikatakan atau tuntas dalam dan $\geq 80 \%$. Persentase ketuntasan klasikal siswa pertemuan 2. Rendahnya pertemuan ini banyak aktivitas yang sukar dalam melakukan curah pendapat, mencari informasi melalui diskusi tersebut, serta proses diskusi dan tanya jawab yang masih kurang, dikarenakan siswa kurang percaya diri atau malu-malu dalam mengemukakan pendapatnya. Ini disebabkan siswa masih terbiasa dengan gaya belajar lama, sehingga aktivitas siswa dalam bekerja secara kelompok masih kurang, yang berdampak pada dalam pertemuan selanjutnya, bisa meningkatkan interaksi antar siswa dalam bekerja sama secara kelompok dan juga atau dorongan memiliki sikap mengemukakan pendapatnya.

\section{Pembelajaran PAI dengan TAI pada Siklus II \\ a. Pelaksanaan Pembelajaran}

Pembelajaran siklus II dilaksanakan sebanyak dua kali pertemuan dengan 4 jam pelajaran. Berikut gambaran pelaksanaan pembelajaran pada siklus II. 


\section{1) Pertemuan 3} berikut:

Pembelajaran berlangsung selama dua jam pembelajaran. Adapun gambarannya sebagai

Memasuki ruang kelas kemudian "Assalamuaalaikum. Wr. Wb" "selamat pagi anak-anak" setelah itu guru. Setelah siswa rapi tertib guru memberikan belajar kepada siswa sehingga siswa termotivasi dalam belajar. Guru mangajukan pertanyaan oleh siswa. Guru membentuk diarahkan untuk dapat cepat dalam membentuk kelompok belajar.Guru menyajikan materi pelajaran dengan menggunakan alat bantu atau media pembelajaran, kemudian guru mengaktifkan siswa dengan individu, guru juga bahwa keberhasilan individu tergantung dari keberhasilan kelompok, guru meminta siswa mengerjakan tugas sesuai kempuannya kemudian tugas yang sudah dikerjakan dibawa kekelompok masing-masing untuk didiskusikan dan perwakilan kerja kelompoknya. Siswa secara berkelompok bergantian dalam maju kedepan kelas menyampaikan hasil dari diskusinya. Guru membimbing siswa menyimpulkan, kemudian guru memberikan umpan balik terhadap pembelajaran.

2) Pertemuan 4 berikut:

Pembelajaran berlangsung selama dua jam pembelajaran. Adapun gambarannya sebagai

Memasuki ruang kelas kemudian "Assalamuaalaikum. Wr. Wb "selamat pagi anak-anak" setelah itu guru Setelah siswa rapi tertib guru memberikan belajar kepada siswa sehingga siswa termotivasi dalam belajar. Guru membentuk diarahkan untuk dapat cepat dalam membentuk kelompok belajar.Guru menyajikan materi pelajaran dengan menggunakan alat bantu atau media pembelajaran, kemudian guru mengaktifkan siswa dengan individu dalam guru juga bahwa keberhasilan individu tergantung dari keberhasilan kelompok,guru meminta siswa mengerjakan tugas sesuai kempuannya kemudian tugas yang sudah dikerjakan dibawa kekelompok masing-masing untuk didiskusikan dan dibahas perwakilan kerja kelompoknya. Berkelompok dalam menyampaikan dari diskusinya. Bersama-sama dengan menyimpulkan pembelajaran yang telah dilaksanakan. Guru memberi pertanyaan beberapa, kemudian soal evaluasi. Setelah evaluasi selesai, pelajaran memberikan nasehat dan terakhir, guru mengucapkan salam.

\section{b. Hasil Observasi}

1) Hasil Observasi Aktivitas Guru

Aktivitas guru pada pertemuan 3 siklus II menunjukkan peningkatan menjadi 20 point. Hal ini disebabkan oleh guru yang terus melakukan perbaikan-perbaikan pada aspek yang dirasa masih kurang penerapannya. Sedangkan pertemuan ke 4, dari 22 indika ini terlaksana dengan sangat baik pada setiap aspeknya. Dalam pertemuan ini aktivitas aktivitas guru dari sehingga dikatakan berhasil dalam menigkatkan aktivitas guru.

2) Hasil Observasi Aktivitas Siswa

Berdasarkan hasil observasi, aktivitas siswa pada pertemuan 3 siklus II menunjukkan kategori aktif dengan persentase sebanyak $71,43 \%$. Sedangkan pertemuan 4 siklus II, aktivitas siswa meningkat menjadi $85,71 \%$. Peningkatan ini dikarenakan guru terus melakukan perbaikan-perbaikan dalam setiap pertemuannya, sehingga kekurangan-kekurangan tersebut dapat diselesaikan dengan baik. Untuk lebih jelasnya, dapat dilihat pada bagan berikut : 


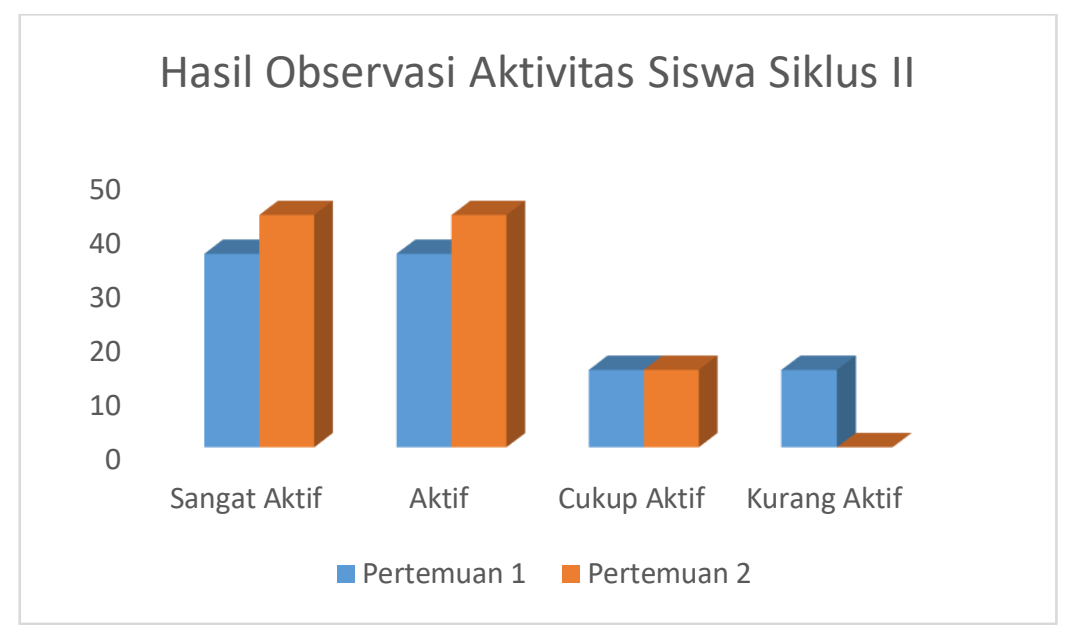

Gambar 4. Diagram Hasil Observasi Aktivitas Siswa Siklus II

3) Hasil Belajar

Pada pertemuan ketiga siklus II, sebanyak 3 siswa mendapatkan nilai 100; 3 siswa mendapatkan nilai 90; 3 siswa mendapatkan nilai 80;2 siswa mendapatkan nilai 70; 2 siswa mendapatkan nilai 60; dan 1 siswa mendapatkan nilai 50. Oleh sebab itu, ada 11 siswa atau 78,57\% yang nilainya tuntas di atas KKM dan 3 siswa atau 21,43\% yang nilainya masih di bawah KKM. Pada pertemuan keempat siklus II, sebanyak 4 siswa mendapatkan nilai 100; 3 siswa mendapatkan nilai 90; 3 siswa mendapatkan nilai 80; 3 siswa mendapatkan nilai 70; dan 1 siswa mendapatkan nilai 60. Dengan demikian, sebanyak 13 siswa nilainya di atas KKM, dan 1 orang siswa nilainya di bawah KKM. Berikut bagan hasil belajar pertemuan 3 dan 4 pada siklus II.

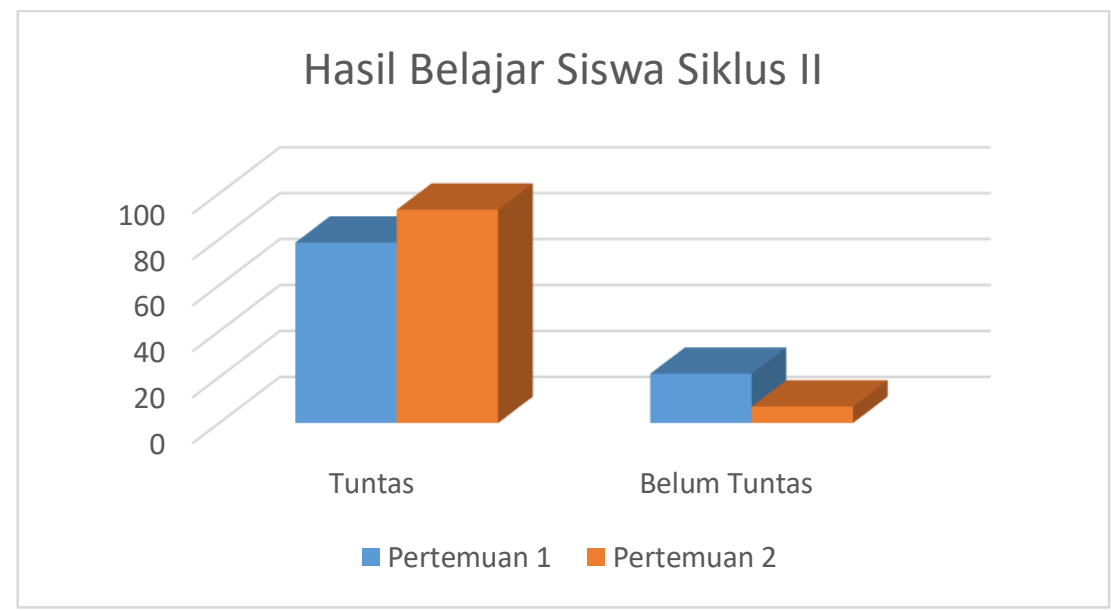

Gambar 5. Diagram Hasil Observasi Aktivitas Siswa Siklus II

\section{c. Refleksi}

Proses pembelajaran semua aspek telah dilakukan oleh guru, dan pada mengalami peningkatan terlaksana sangat terlihat dari skor yang diperoleh oleh guru. Hal ini disebabkan guru terus melakukan perbaikan-perbaikan pada aspek yang dirasa masih kurang penerapannya. Dengan demikian, pada pertemuan ini aktivitas guru telah mencapai. Pada pertemuan ini aktivitas siswa memperoleh kategori aktif dan ketuntasan klasikalnya 71,43 hampir rata-rata sudah mulai, hanya saja beberapa kurang aktif, diantaranya seperti aspek bekerjasama secara aktif dengan teman sekelompoknya, karena dalam proses pembelajaran masih jawaban dari teman lainnya. Padahal setelah diamati oleh guru, siswa tersebut bisa mengerjakannya. Diharapkan disini guru harus lebih baik lagi memberikan arahan bahwa keberhasilan siswa 
tergantung dari keberhasilan kelompok, sehingga siswa dapat antusias dalam kerja kelompok. Ini nilai ketuntasan yaitu dengan persentase $78,57 \%$. Keterlibatan guru dalam pertemuan ini sudah lebih baik, hanya saja ada yang nilainya masih dibawah KKM yang ditetapkan. Meskipun belum dapat mencapai hasil yang maksimal, akan tetapi hasil tersebut sudah cukup memuaskan.

\section{Pembahasan}

Pada aktivitas guru proses pembelajaran, guru melakukan refleksi aktivitas guru sehingga dapat diketahui apa kekurangan dalam pembelajaran tersebut. Dengan adanya refleksi guru dapat merencanakan solusi untuk mengatasi apa yang belum tercapai pada pembelajaran tersebut. Setelah adanya solusi guru melakukan perbaikan pelaksanaan pembelajaran. Perbaikan ini dilakukan agar guru dapat memperbaiki kualitas pengajaran yang lebih baik lagi.Penilaian kelas dan klasikal) dalam dapat pada gambar berikut :

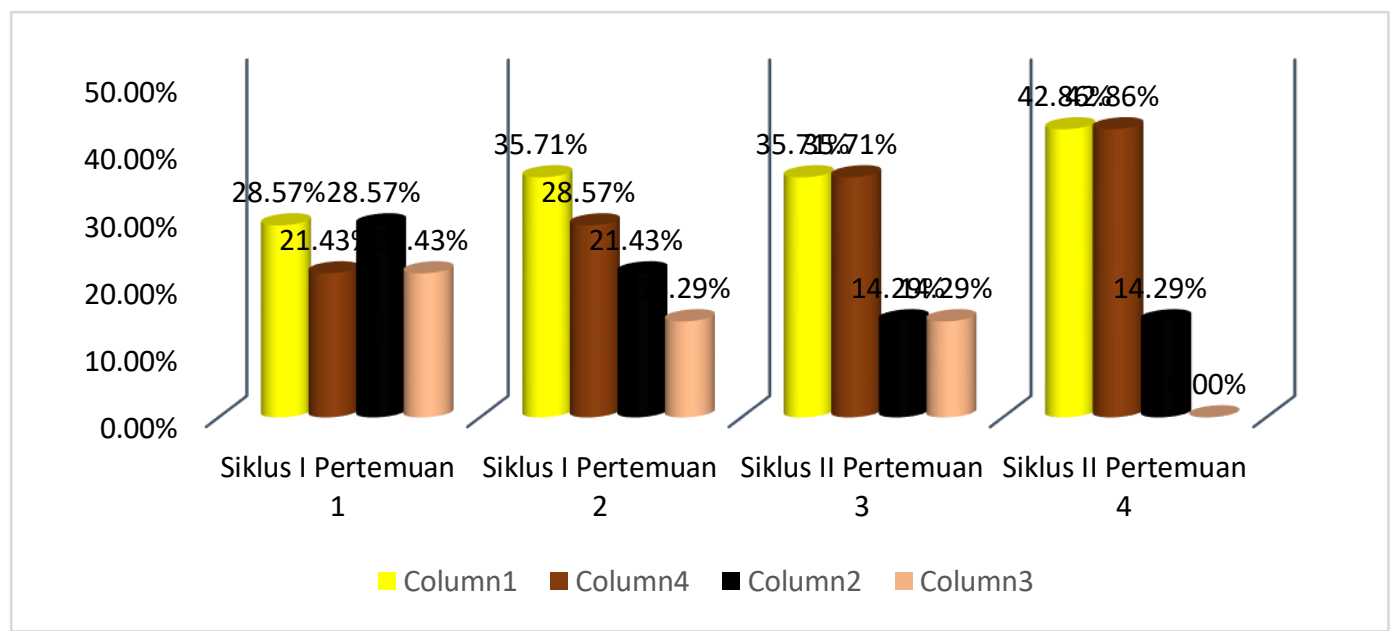

Gambar 6. Diagram Hasil Observasi Aktivitas Guru Siklus I dan II

Hasil belajar siswa kelas V pada materi tersebut dalam siklus I dan II dapat dibandingkan pada diagram berikut.

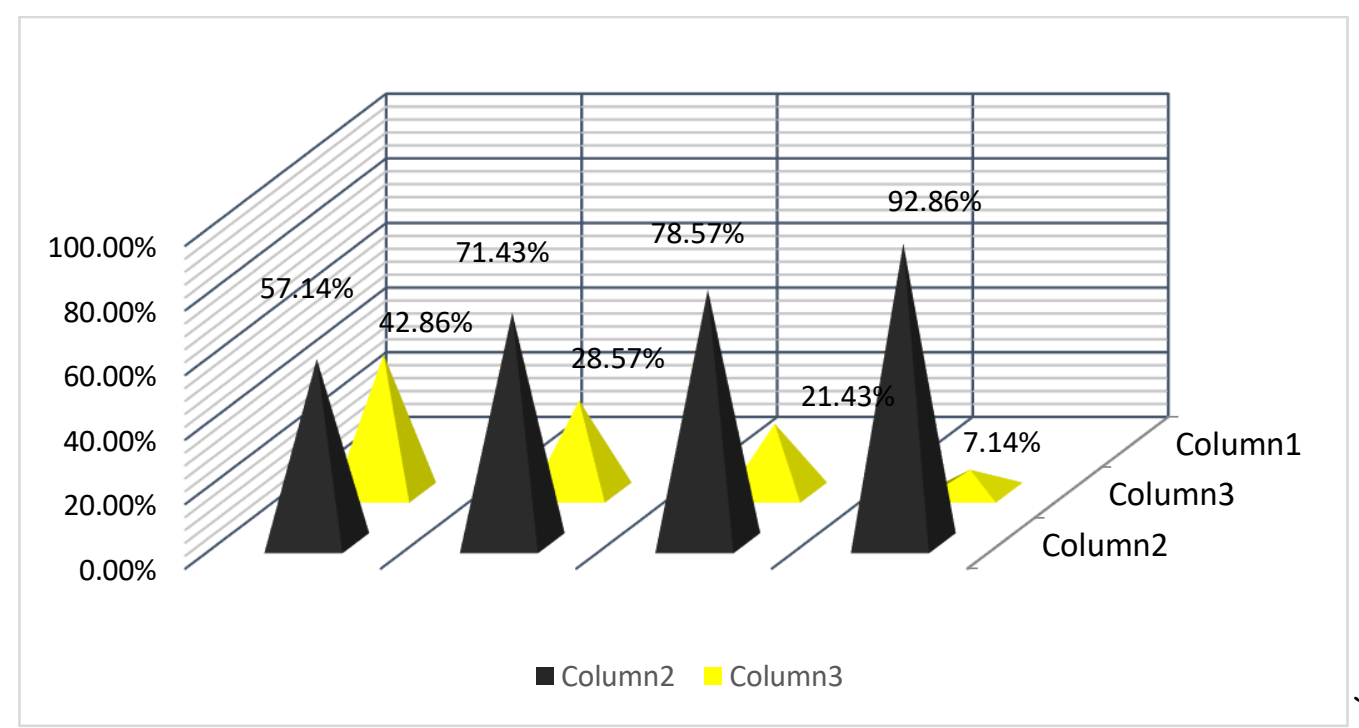

Gambar 7. Diagram Hasil Belajar Siswa Siklus I dan II

Berdasarkan hasil observasi serta guru Khalifah Abu Bakar R.A di SDN Mekar Sari Tatah Makmur Banjar Pelajaran 2018/2019, baik dapat setiap pertemuannya telah terlaksana. Terjadi dikarenakan berusaha memperhatikan memperbaiki aktivitas yang telah dilakukan pada 
pertemuan sebelumnya agar pembelajaran menjadi lebih efektif. Upaya perbaikan ini dilakukan guru dengan merencanakan kembali strategi-strategi untuk pembelajaran berikutnya berdasarkan refleksi dari pertemuan sebelumnya. Aspek-aspek yang belum dilaksanakan secara maksimal dipertemuan sebelumnya dicatat dan diidentifikasi kekurangan-kekurangan dalam pelaksanaannya sehingga guru dapat menemukan solusi untuk meminimalisir kekurangan tersebut agar pada pertemuan berikutnya pembelajaran dapat dilaksanakan lebih baik lagi.

Serta analisis data Pendidikan Agama Islam materi Kisah Khalifah Abu Bakar R.A. menggunakan pada Mekar Sari Tatah Makmur Banjar Pelajaran 2018/2019, baik pada, terlihat ditiap pertemuannya dan bahkan pada pertemuan 2 secara klasikal sangat aktif. Keaktifan pembelajaran ditunjukkan pula oleh siswa yang senang dan bersemangat dalam kegiatan belajar. Mereka aktif mengemukakan pendapatnya dalam diskusi kelompok serta bersemangat untuk melakukan kegiatan yang cocok.

Suriansyah, dkk (2010: 263) mengemukakan bahwa indikator keterlibatan siswa dalam pembelajaran dapat dilihat melalui kegiatan mengajar menjadi semakin bahkan sangat aktif. Adanya peningkatan keaktifan dan hasil belajar siswa pada pembelajaran menggunanakan model TAI, didukung oleh hasil penelitian berikut:

a. Jirin. 2012. Meningkatkan Hasil Belajar Siswa pada Konsep Malaikat Allah SWT di Kelas V SDN Banjarbaru Loktabat 7. Hasil penelitian dapat disimpulkan bahwa hasil kelas 50\% pada siklus 1 dan (95\%) pada siklus 2 dengan kategori cukup menjadi sangat baik.

b. Kani. 2012. Meningkatkan Hasil Belajar Siswa pada Konsep Surah Al-Kautsar di Kelas V SDN Banjarbaru Kota 1. Ketuntasan belajar mencapai $90 \%$ pada siklus II dalam materi Surah Al Kautsar.

Bahwa pada materi Kisah Khalifah Abu Bakar R.A. menggunakan TAI maka hasil belajar siswa SDN Mekar Sari Tatah Makmur Banjar Pelajaran 2018/2019” dapat diterima.

\section{PENUTUP}

Berdasarkan uraian tersebut, maka dapat disimpulkan bahwa:

1. Aktivitas guru dalam pembelajaran materi Kisah Khalifah Abu Bakar R.A. dengan menggunakan TAI pada SDN Mekar Sari Tatah Makmur Banjar Pelajaran 2018/2019 telah terlaksana sangat baik.

2. Aktivitas siswa SDN Mekar Sari Tatah Makmur Banjar Pelajaran 2018/2019 dalam mengikuti TAI semakin mencapai kategori sangat aktif pada siklus II pertemuan 2.

3. Ketuntasan hasil belajar siswa SDN Mekar Sari Tatah Makmur Banjar Pelajaran 2018/2019 pada siklus I mencapai 57,14\% pada pertemuan kesatu dan kedua sebesar 71,43\%. Pada siklus II, ketuntasan klasikal mencapai $78,57 \%$ pada pertemuan ketiga dan mencapai $92,86 \%$ pada pertemuan keempat.

\section{DAFTAR PUSTAKA}

Arikunto, Suharsimi, dkk. 2006. Penelitian Tindakan Kelas. Jakarta: Bumi Aksara.

BNSP. 2007. Permendiknas RI Nomor 41 tahun 2007 Standar Proses untuk Satuan Pendidikan Dasar dan Menengah. Jakarta: Depdiknas.

Jirin . 2012. Meningkatkan Hasil Belajar Siswa pada Konsep Malaikat Allah SWT di Kelas V SDN Banjarbaru Loktabat 7 . Skripsi: Universitas Lambung Mangkurat (tidak dipublikasikan).

Kani . 2012. Meningkatkan Hasil Belajar Siswa pada Konsep Surah Al-Kautsar di Kelas V SDN Banjarbaru Kota 1 . Skripsi: Universitas Lambung Mangkurat (tidak dipublikasikan).

Pemerintah RI. 2006. Undang-undang Republik Indonesia Nomor 20 Tahun 2003 Tentang Sistem Pendidikan Nasional. Jakarta: Citra Umbara. 
Suriansyah, Ahmad, dkk. 2009. Strategi Pembelajaran. Banjarmasin: Universitas Lambung Mangkurat. 